\title{
NEW DIPTERA IN THE U. S. NATIONAL MUSEUM.
}

By D. W. Coquillett,

Custodian, Section of Diptera.

In the course of identifying the New Jersey diptera for Dr. J. B. Smith's excellent list of the insects of that State, Mr. C. W. Johnson, curator of the Wagner Free Institute, of Philadelphia, encountered quite a series of specimens belonging to obscure groups which he was unable to identify within the limited time allowed him for this purpose, and consequently submitted them to the writer for study. Mr. Johnson permitted the retention for the U. S. National Museum collection of specimens pertaining to species not already represented therein, the only conditions being that the data from the labels be sent him, together with the names of the known forms and manuscript names of such as were believed to be new to science. As these manuscript names have now been published it is deemed advisable to publish descriptions of these species and thus render permanent the names which would otherwise have no value. Accordingly, these descriptions are offered herewith, together with a number of those of other forms encountered when identifying specimens for correspondents, or while studying and comparing the Museum collection. These make a total of 2 genera and 71 species.

\section{Family MYCETOPHILID Æ.}

\section{BOLITOPHILA MONTANA, new species.}

Dark brown, the base of the third antennal joint, peduncle of the halteres, coxæ, femora and tibiæ light yellow, sides of mesonotum largely brownish yellow, mesonotum polished; wings hyaline, stigma elongate oval, gray; auxiliary vein reaches only slightly beyond middle, between humeral cross vein and base of third vein, anterior branch of third vein terminates in the costa, fourth vein at its base coalescing for a short distance with the upper branch of the fifth near its base; length, $4.5 \mathrm{~mm}$. A female specimen, collected by Mrs. A. T. Slosson.

Habitat.-Mount Washington, New Hampshire.

Type.-Cat. No. 5438, U.S.N.M.

Proceedings U. S. National Museum, Vol. XXIII-No. 1225.

Proc. N. M. vol. xxiii- 38 
MACROCERA NEBULOSA, new species.

Yellow, the antennæ except the base, three large spots on the pleura, knobs of halteres, bases of abdominal segments two to five and whole of abdomen beyond the fifth segment in the male, the base of each segment except the first in the female, also the tarsi, dark brown; body polished; wings bare, hyaline, marked with four irregular brown fascix; the first begins at apex of auxiliary vein and extends to the anal angle; the second extends from apex of first vein to apex of the sixth, and is almost, or quite, interrupted in the fourth posterior cell; the third extends from anterior branch of third vein to apex of anterior branch of the fifth, while the last one borders apex of wing and is connected with the preceding one along the third vein and both branches of the fourth; length, 4 to $5 \mathrm{~mm}$. Two males and one female.

Habitat.-Mount Washington and Franconia, New Hampshire (Mrs. A. T. Slosson), and Clementon, New Jersey (Mr. C. W. Johnson).

Type.-Cat. No. 5439, U.S.N.M.

\section{CEROPLATUS CLAUSUS, new species.}

Yellow, upper part of head brownish yellow, a black ocellar dot, the antennæ, four indistinct vittæ on mesonotum, one or two spots on pleura, a fascia at base of each segment of abdomen and knobs of halteres, brown; antennæ greatly compressed, the joints except last one wider than long; wings hyaline, a grayish brown spot fills the submarginal cell and encroaches on the adjoining cells; auxiliary vein extends considerably beyond base of third vein; auxiliary cross vein close to the humeral, upper branch of third vein ends in the first at about its length before apex of the latter, costa scarcely extending beyond apex of third vein, fifth vein forks considerably beyond base of the third; length, 7 to $8 \mathrm{~mm}$. A specimen of each sex.

Habitat. - Franconia, New Hampshire (Mrs. A. T. Slosson), and New Brunswick, New Jersey (Dr. J. B. Smith).

Type.-Cat. No. 5440, U.S.N.M.

PLATYURA INOPS, new species.

Yellow, an ocellar dot and apices of abdominal segments black, most extended on the posterior segments, tarsi yellowish brown; antennæ subcylindrical, the third joint noticeably longer than broad (apical portion of antennæ wanting in all the specimens); wings hyaline, a grayish brown spot before apex of third vein; auxiliary vein extending a short distance beyond base of the third, auxiliary cross vein at about one-sixth of distance from the humeral to apex of auxiliary vein, upper branch of third vein ending in the costa at about one-third of distance from apex of first vein to apex of the third, costa extending nearly midway between apices of third vein and upper branch of the 
fourth, fifth vein forking beyond base of the third; length, $4.5 \mathrm{~mm}$. Three male specimens, collected by Mr. C. W. Johnson.
Habitat.-Delaware Water Gap, New Jersey.
Type.-Cat. No. 5441, U.S.N.M.

TETRAGONEURA BICOLOR, new species.

Head black, first two joints of antennæ and the mouth parts yellow, remainder of antennæ dark brown; thorax and scutellum black, somewhat polished, the hairs reddish brown and black; abdomen yellow, its hairs also yellow; halteres, coxæ, femora, and tibiæ yellow, apices of tarsi brownish yellow; wings hyaline, auxiliary vein ending in the first about midway between the humeral cross vein and base of third vein, fifth vein forking close to its base; length, $3.5 \mathrm{~mm}$. A female specimen, collected by Mrs. A. T. Slosson.

Habitat.-Franconia, New Hampshire.

Type.-Cat. No. 5442 , U.S.N.M.

TETRAGONEURA PIMPLA, new species.

Head black, base of antennæ and the mouth parts yellow; body brown, two indistinct vittæ and lateral margins of mesonotum, a spot above front coxæ, posterior margins of second and following abdominal segments, and the genitalia, yellow; hairs and bristles of thorax black, those of abdomen chiefly yellowish brown; coxæ and femora yellow, tibiæ and tarsi brownish yellow, halteres yellow; wings grayish hyaline, the auxiliary vein ends in the first nearly midway between the humeral cross vein and base of third vein, fifth vein forks near its middle, at a point almost opposite the union of the small cross vein with the fourth vein; length, $4.5 \mathrm{~mm}$. A female specimen, collected June 16, 1895, by Mr. C. W. Johnson.

Habitat.-Montgomery County, Pennsylvania.

Type:-Cat. No. 5443 , U.S.N.M.

SCIOPHILA SUBCARULEA, new species.

Black, polished and strongly tinged with blue, the mouth parts brownish yellow, antennæ dark brown, a yellow spot on each prothoracic spiracle; coxæ, femora, and tibiæ, yellow, the tarsi brownish yellow, halteres yellowish brown, the apices and peduncles yellow; hairs of mesonotum short, depressed, yellow, those of the sides, head, and abdomen rather long and black; wings densely hairy, grayish hyaline, a brownish spot at the small cross vein and a second beneath apex of first vein; fifth vein forking before base of third, marginal cell about as broad as long; front tibiæ noticeably shorter than the first joint of their tarsi, middle femora each bearing a robust, outwardly directed spine on the under side a short distance before the apex. 
Female.-Differs from the male as follows: Apical portion of antennæ beyond the seventh joint light yellow; abdomen, except the first segment and dorsum of the second, reddish yellow; coxæ, fiont tibiæ and their tarsi, also the hind femora except their ends black or brown; middle of middle femora brownish; the long hairs of head and body yellow; middle femora destitute of spines.

Length, 9 to $13 \mathrm{~mm}$. Two males and two females.

Mabitat.-Franconia, New Hampshire (Mrs. A. T. Slosson); North Mountain, Pennsylvania (Mr. C. W. Johnson); and Ottawa, Canada (Mr. W. H. Harrington).

Type.-Cat. No. 5444 , U.S.N.M.

SCIOPHILA FLAVOHIRTA, new species.

Head black, the face and mouth parts yellow, first two joints of antennæ yellow, the remainder black, compressed, the third joint only slightly longer than broad; thorax and scutellum yellow, polished, the bristles and numerous, rather long hairs also yellow; abdomen polished, yellow, the bases of segments two to five, the whole of the sixth, and apex of abdomen, black; legs yellow, the tarsi brownish; halteres yellow; wings hyaline, marginal cell about twice as long as broad, fifth vein forking far before base of third; front tibiæ slightly longer than their tarsi; length, $5 \mathrm{~mm}$. A male specimen, collected by Mrs. A. T. Slosson.

Habitat.-Franconia, New Hampshire.

Type.-Cat. No. 5445, U.S.N.M.

POLYLEPTA TIBIALIS, new species.

Head black, the face yellow and rather densely covered with bristly hairs; antennæ brown, the bases yellow, the third joint about twice as long as wide; mouth parts yellow, the penultimate and antepenultimate joints of palpi with a leaf-like prolongation at the upper side of their outer ends; thorax polished, yellow, two approximated vittæ on the mesonotum and a transverse row of three spots on the metanotum dark brown, the hairs and bristles black; scutellum brownish yellow; abdomen yellow, the broad apices of the segments, sometimes crossing the segment in the middle of the dorsum, dark brown; halteres and legs yellow, the tarsi yellowish brown; front tibiæ each with a deep groove before apex of anterior side, extending about one-third length of tibia; wings grayish hyaline, costal cell tinged with yellow, auxiliary vein obliterated at its apex, the cross vein slightly before base of third vein, fifth vein forking opposite the marginal cell; length, $5 \mathrm{~mm}$. Three female specimens, collected by H. K. Morrison.

Habitat.-White Mountains, New Hampshire.

Type.-Cat. No. 5446, U.S.N.M.

I have also examined specimens collected by Mr. C. W. Johnson at Westville and Delaware Water Gap, New Jersey. 


\section{DOCOSIA LONGICORNIS, new species.}

Yellow, the front, vertex, antennæ except the two hasal joints, three vittæ on mesonotum, dorsum of first abdominal segment except a spot on each side, a fascia at base of remaining segments and the geritalia, black; tarsi becoming brown toward their apices; antennæ more than twice as long as the head and thorax, the third joint over twice as long as wide; body polished, its hairs and those of the coxæ and femora yellow; wings hyaline, the auxiliary vein ends in the first slightly beyond middle of first basal cell, small cross vein less than twice as long as first section of third vein, fifth vein forking before the small cross vein; length, $5 \mathrm{~mm}$. A male specimen, collected by H. K. Mowrison.

Mabitat.-White Mountains, New Hampshire.

Type.-Cat. No. 5447, U.S.N.M.

DOCOSIA OBSCURA, new species.

Black, the halteres and legs yellow, bases of coxæ, femora on base of under side, and the tarsi, brown; third joint of antennæ only slightly longer than broad; body polished, the hairs yellow; bristles of hind tibiæ shorter than greatest diameter of the tibiæ; wings hyaline, veins brownish, auxiliary vein ends in the first, small cross vein at least four times as long as first section of third vein, fourth and fifth veins fork about opposite first section of the third, sixth vein almost reaching forking of the fifth; length, 3 to $3.5 \mathrm{~mm}$. Three male specimens, collected by H. K. Morrison.

Mabitat. - White Mountains, New Hampshire.

Type.-Cat. No. 5448, U.S.N.M.

\section{DOCOSIA VITTATA, new species.}

Head black, the face, mouth parts, and broad base of antennæ yellow, third joint of antennæ only slightly longer than broad; body polished, brown, a median vitta on the mesonotum, expanded at the front end and crossing the pleura, also middle of breast yellow, middle of metanotum reddish yellow; hairs of thorax black; halteres and legs yellow, changing into brown at apices of the tarsi; bristles of hind tibiæ longer than greatest diameter of the tibiæ; wings grayish hyaline, the auxiliary vein ends in the first, small cross vein about twice as long as first section of third vein, fifth vein forking far before the forking of the fourth, sixth vein reaching over one-fourth of its length beyond forking of the fifth; length, $4 \mathrm{~mm}$. A male specimen, collected by Mrs. A. T. Slosson.

Habitat.-Franconia, New Hampshire.

Type.-Cat. No. 5449, U.S.N.M.

LEPTOMORPHUS PARVULUS, new species.

Yellow, a brownish ocellar spot, hind margins of second to fifth abdominal segments and whole of the sixth and seventh black, a black 
dot on each trochanter, tarsi toward the apices brown (antennæ beyond the third joint wanting in the single specimen under observation); body polished; hairs of thorax yellow; wings hyaline, the broad apices gray, sixth vein extending beyond middle of lower fork of the fifth; length, $3.5 \mathrm{~mm}$. A male specimen, collected July 12, by Mr. C. W. Johnson.

Habitat.-Delaware Water Gap, New Jersey.

Type.-Cat. No. 5450, U.S.N.M.

LEPTOMORPHUS HYALINUS, new species.

Yellow, an ocellar dot and the mesonotum, except the lateral margin, interrupted above insertion of wings, black; antennæ, except the two basal joints, brown; abdomen with indications of an irregular brown fascia at apex of each segment; body polished; wings hyaline, densely short haired; length, $9 \mathrm{~mm}$. Two female specimens, collected by H. K. Morrison.

Mabitat. - White Mountains, New Hampshire.

Type.-Cat. No. 5451, U.S.N.M.

ACNEMIA FLAVEOLA, new species.

Yellow, the antennæ and tarsi becoming brown toward their apices, segments two to six of abdomen, each with a median brown fascia, shortest on the second and third, a brown dot on underside of each trochanter; bristles of tibiæ much shorter than greatest diameter of the tibiæ; wings hyaline; length, $3 \mathrm{~mm}$. A female specimen, collected July 11, by Mr. C. W. Johnson.

Habitat.-Delaware Water Gap, New Jersey.

Type.-Cat. No. 5452, U.S.N.M.

EXECHIA ANALIS, new species.

Head black, the face, mouth parts, and base of antennæ yellow; thorax black, slightly polished, a small, triangular, yellow spot below the humeri; abdomen dark brown, the third and fourth segments, except hind margin of the latter, yellow; legs yellow, the broad apices of hind femora dark brown, tarsi brownish yellow, bristles of hind tibiæ noticeably longer than greatest diameter of the tibiæ; wings hyaline, a brown fascia fills apex of marginal cell and crosses the first posterior; length, 2 mm. A male specimen, collected July 8, by Mr. C. W. Johnson.

Habitat.-Delaware Water Gap, New Jersey.

Type.-Cat. No. 5453, U.S.N.M.

DYNATOSOMA THORACICA, new species.

Head black, upper part of face, base of antennæ, and the mouth parts yellow; thorax and scutellum black, subopaque; abdomen dark 
brown, the first four segments partly or wholly reddish yellow; halteres and legs yellow, tarsi brownish, anterior tibiæ each bearing about four downwardly directed spines at apex of outer side, the ancerior spine the longest, nearly half as long as the tibial spur; many of the lateral bristles of middle and hind tibiæ much longer than greatest diameter of the tibiæ, those on inner side of the middle tibiæ shorter than greatest diameter of the latter; wings grayish hyaline, tinged with yellowish along the costa, fifth vein forking about opposite the small cross vein; length, 4 to $5 \mathrm{~mm}$. Two males and two females.

Habitat.-Carlinville, Illinois (Mr. Charles Robertson); Mount Washington and Franconia, New Hampshire (Mrs. A. T. Slosson), ano White Mountains, New Hampshire (H. K. Morrison).

\section{Type.-Cat. No. 5454, U.S.N.M.}

[Mycetophila hopkinsii Coquillett belongs more properly to the genus Leja, and Neoglaphyroptera beringensis Coquillett to Boletina.

\section{Family CHIRONOMIDA.}

\section{CERATOPOGON Meigen.}

In order to facilitate the identification of the new species, thein descriptions are given in the form of a synoptic table, as follows:

1. Third vein partly or wholly contiguous to the first, or connected with it by a

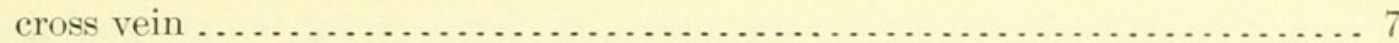

Third vein wholly separated from the first, wings bare, unspotted, penultimate joint of hind tarsi at most one-half as long as the last joint, tarsal claws equal or nearly equal in length . . . . . . . . . . . . . . . . . . . . . . . . . . 2

2. Last joint of hind tarsi bearing several spinous bristles on the under side, mesono-

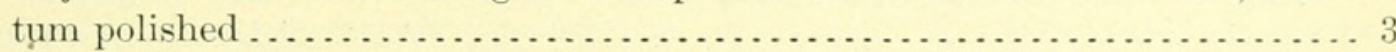

Last joint destitute of spinous bristles.......................... 4

3. Wings, including the veins, white. Head black, eyes widely separated, antennæ yellow, the apical half and the large basal joint brown, mouth parts brown; thorax and scutellum black, halteres whitish, abdomen yellow, legs whitish, apical half of femora, last tarsal joint, and apices of hind tibiæ black; femora slender, destitute of spinous bristles, first tarsal joint at least twice as long as the second, the latter slightly shorter than the last one; claws simple, about threefourths as long as the last tarsal joint; third vein ending close to the extreme wing tip, fourth vein forking before the small cross vein; length, $2 \mathrm{~mm}$.

elegans, new species.

A female specimen, collected May 14, by Mr. C. W. Johnson. Riverton, New Jersey.

\section{Type.-Cat. No. 5455, U.S.N.M.}

Wings hyaline, smoky brown in front of third vein, veins largely brown. Head black, eyes almost contiguous, face brownish yellow, antennæ white, the apical half brownish, the basal joint and mouth parts yellow; thorax and scutellum black, halteres and abdomen yellow, dorsum of segments 3 to 6 black, legs black, apices of coxæ, trochanters and bases of femora yellow, first four joints of tarsi whitish; femora slender, destitute of spinous bristles, tarsal joints and claws as 
in the preceding species; third vein ending close to wing tip, fourth forking close to small cross vein; length, $2 \mathrm{~mm} . . . . . . . . . . . . . . .5$ smithi, new species.

A female specimen, collected June 16, by Mr. C. W. Johnson; dedicated to Dr. J. B. Smith. Riverton, New Jersey.

Type.-Cat. No. 5456 , U.S.N.M.

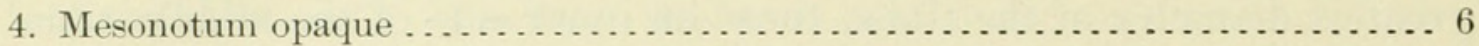

Mesonotum polished . . . . . . . . . . . . . . . . . . . . . . . . 5

5. Front femora each bearing 2 spinous bristles on apical half of under side, other femora destitute of them. Head and its members black (antennæ, except the first joint, wanting), eyes quite widely separated; mesonotum and scutellum black, pleura and abdomen dark brown, knob of halteres brown, legs dark brown, front femora almost wholly, the base and a ring before apex of front and middle tibiæ, also the tarsi except apices of the joints, light yellow; first joint of hind tarsi almost twice as long as the second; last joint about two-thirds as long as the second, claws simple, nearly half as long as last tarsal joint; wings hyaline, veins yellowish, apex of third vein at three-fourths lengtil of wing, apex of first vein near middle of the third, fourth forking considerably beyond the small cross vein; length, $2 \mathrm{~mm}$................ expolitus, new species. A male specimen, collected July 3, by Mr. C. W. Johnson. Riverton, New Jersey.

$$
\text { Type.-Cat. No. 5457, U.S.N.M. }
$$

Front and other femora bearing spinous bristles on nearly the entire length of under side. Head black, eyes rather broadly separated, antennæ brown, sutures of the joints whitish, the basal joint yellowish brown, mouth parts dark brown; body black, knobs of halteres and legs dark brown, a ring before apex of each front femur, base of front tibiæ, a ring before apex of each front and middle tibia, also the tarsi, except apex of each joint, light yellow; first joint of hind tarsi nearly twice as long as the second, the latter slightly longer than the last one, claws more than half as long as last tarsal joint, one on each tarsi bearing a tooth near middle of under side; wings hyaline, pale grayish along the costa, apex of third vein near four-fifths length of wing, apex of first at one-third length of the third, fourth forking close to the small cross vein; length, $2.5 \mathrm{~mm}$.

johnsoni, new species.

A female specimen, collected July 3, by Mr. C. W. Johnson, for whom the species is named. Riverton, New Jersey.

\section{Type.--Cat. No. 5458, U.S.N.M.}

6. Under side of each front femur bearing at least 5, each middle femur about 2 , each hind one about 4 spinous bristles. Head dark brown, eyes rather narrowly separated, antennæ brown, the basal half yellow at sutures of joints, palpi yellow, proboscis brown; thorax dark brown, light gray pruinose, a median brown vitta on anterior half and a transverse row of four elongated brown spots across the middle, scutellum yellow, knobs of halteres brown; abdomen black, opaque, thinly gray pruinose; legs dark brown, front and middle femora except their apices, usually the middle of the hind femora, front tibiæ except their apices, a ring before apices of middle and usually of the hind tibiæ, also the tarsi, except apices of the joints, light yellow; first tarsal joint almost twice as long as the second, the latter one and one-fourth times as long as the last one, claws slightly more than half as long as last tarsal joint, one on each tarsi bearing a tooth near middle of under side; wings hyaline, apex of third vein near four-fifths length of wing, apex of first slightly before middle of the third, fourth forking slightly before or at the small cross vein; length, nearly $3 \mathrm{~mm}$. pulvereus, new species. 
Three female specimens. Riverton, New Jersey (July 3, C. W. Johnson), and District of Columbia (D. W. Coquillett, in June).

$$
\text { Type.-Cat. No. 5459, U.S.N.M. }
$$

Under side of each femur bearing a single spinous bristle. Head black, eyes quite widely separated, antennæ brown, the basal half yellow at sutures of the joints, mouth parts dark brown; thorax dark brown, light gray pruinose, a dark brown median vitta on anterior half and a widely separated pair on the posterior half, scutellum yellow, knobs of halteres brownish yellow; abdomen dark brown, first two segments, except a pair of spots on the first and the posterior portion of the second, also the narrow hind margin of each segment, yellow; lègs light yellow, the sutures brownish, coxæ dark brown; tarsi and wings as in the preceding species; length, $2 \mathrm{~mm}$......... barberi, new species.

A female specimen, collected May 11, by Mr. H. S. Barber, for whom the species is named. Chesapeake Beach, Maryland.

$$
\text { Type.-Cat. No. 5460, U.S.N.M. }
$$

7. Wings hairy on at least the apical portion, tarsal claws simple, of an equal length, femora and tarsi not spinose ........................... 8

Wings bare, first tarsal joint at least one-half longer than the second . . . . . . 22

8. First tarsal joint at least one-half longer than the second . ............... 11

First joint shorter, or at most only slightly longer than the second, the latter at most one-third longer than the first, last two joints of nearly an equal length, empodia distinct, wings thickly covered with brown hairs, third vein united with the first nearly to apex of the latter, its apical portion separated from the costa, ending near middle of length of wing...................... 9

9. Mesonotum opaque.......................................... 10

Mesonotum polished. Head and its members brownish black, eyes contiguous, pubescence on apical portion of antennæ and at apex of palpi white; body black, its hairs brown, a yellowish spot on pleura in front of each wing, knobs of halteres whitish, legs brown, bases of tarsi yellow, middle and hind legs bearing many long hairs on under side of the femora, outer side of the tibiæ and upper side of the tarsi; wings hyaline, fourth vein forking beyond the small cross vein; length, 2 to $2.5 \mathrm{~mm}$............... specularis, new species.

Four male specimens. Philadelphia (June 28) and Natrona, Pennsylvania (July 30, C. W. Johnson); Washington, District of Columbia (August 11, F. C. Pratt), and Colorado.

$$
\text { Type.-Cat. No. 5461, U.S.N.M. }
$$

10. Tibiæ bearing several lanceolate scales on the outer side. Head dark yellow, eyes contiguous, antennæ basally yellow, the remainder and mouth parts brown; thorax and scutellum dark yellow, abdomen dark brown, body thinly covered with short yellow hairs; knobs of halteres whitish; legs light yellow, destitute of long hairs; wings hyaline, short, broad, very blunt at apex; length, nearly $1 \mathrm{~mm}$................................... fimbriatus, new species.

A female specimen, collected August 11, by Mr. H. S. Barber. Washington, District of Columbia.

\section{Type.-Cat. No. 5462, U.S.N.M.}

Tibiæ destitute of scales. Head and body dark brown, a humeral spot extending upon the pleura almost to front coxæ, a spot beneath each wing, hind margins of abdominal segments 2 to 6 , and ventral portion of first 4 or 5 , light yellow; eyes contiguous, antennæ brownish yellow, the hairs in female largely whitish, in male dark brown, their apices whitish, mouth parts brownish yellow, body 
thickly covered with depressed light yellow hairs and brown and yellow long marginal hairs; legs light yellow, apices of middle and hind femora and bases of their tibiæ pale brownish, outer side of all tibiæ and upper side of hind tarsi beset with many unusually long yellow hairs; knobs of halteres yellowish white; wings hyaline, narrow and rather long; length, 1.5 to almost $2 \mathrm{~mm}$.

pergandei, new species.

A specimen of each sex, collected March 10 by Mr. Th. Pergande, for whom the species is named. Washington, District of Columbia.

\section{Type.-Cat. No. 5463, U.S.N.M.}

11. Apex of third vein near two-thirds or three-fourths length of wing, eyes contiguous............................................... 14

Apex near middle of length of wing, fourth forking beyond the small cross vein, empodia wanting ........................................... 12

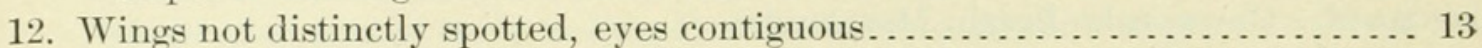

Wings covered with whitish hyaline and dark gray spots. Head black, eyes rather widely separated, antennæ black, base of flagellum yellowish, its joints except last two of nearly an equal length, noticeably longer than broad, mouth parts black; body black, opaque, mesonotum gray pruinose and covered with brown spots, halteres and legs brown, tibiæ bearing several rather long yellow hairs on outer side, a yellow ring before apices of front and middle femora and near bases of their tibiæ, tarsi largely yellow; wings nearly wholly covered with brown hairs, third vein contiguous to the first and to the costal vein, apical portion of first and third veins and costal vein near them greatly dilated, forming a darker spot than any of the others, fourth posterior cell whitish hyaline except a central triangular gray spot extending to the outer angles; length

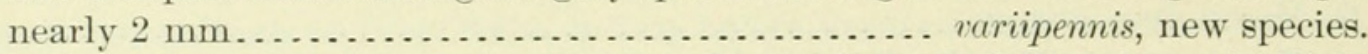

Three female specimens. Westville, New Jersey (July 2, C. W. Johnson); Richmond, Virginia (Mrs. A. T. Slosson); and Mexico City, Mexico (O.W. Barrett).

\section{Type.-Cat. No. 5464, U.S.N.M.}

13. Mesonotum wholly densely gray pruinose, marked with three indistinct dark vittæ. Head black, antennæ and proboscis brown, palpi yellow; body black, the humeri, a large spot on pleura beneath wing, the scutellum, hind margins of abdominal segments, and the venter, yellow; halteres and legs yellow, sutures of the joints of latter brown; wings hyaline, almost wholly covered with brown hairs, third vein coalescing with the first nearly to apex of the latter, then extending close to the costa for a short distance; length, $1 \mathrm{~mm}$.

griseus, new species.

Two female specimens. Washington, District of Columbia (June 9, H. S. Barber); and Lake Worth, Florida (Mrs. A. T. Slosson).

Type.-Cat. No. 5465, U.S.N.M.

Mesonotum opaque black, somewhat velvety, in certain lights thinly whitish pruinose. Head and its members black, hairs of male antennæ brown, their apices whitish, body black, humeri, scutellum, and halteres light yellow, legs dark yellow; wings hyaline, almost wholly covered with brown hairs, third vein coalescent with the first nearly to apex of the latter, then extending a short distance close to the costal vein; length, $0.5 \mathrm{~mm}$.. mutabilis, new species.

Five males and 14 females. Washington, District of Columbia (on windows, June 5 to 8, H. S. Barber); and Jacksonville, Florida (Mrs. A. T. Slosson).

Type.-Cat. No. 5466, U.S.N.M. 
14. Empodia wanting. . . . . . . . . . . . . . . . . . .

Empodia distinct, obovate, fringed with short bristles. Black, the legs brownish yellow, knobs of halteres whitish; joints 3 to 5 of antennæ broader than long, mesonotum polished (abraded ?), the front corners opaque, legs destitute of long hairs; wings hyaline, almost wholly covered with brown hairs, third vein connected by a cross vein with the first, elsewhere distinctly separated from it, reaching slightly beyond two-thirds length of wing, apex of $\mathrm{fi}$ : $t \mathrm{t}$ near two-fifths length of third, fourth forking beyond the small cross vein; length, slightly over $1 \mathrm{~mm}$............................. vebsteri, new species.

Four females collected April 17, 1887, by Prof. F. M. Webster, for whom the species is named. Ashwood, Louisiana.

\section{Type.-Cat. No. 5467, U.S.N.M.}

15. Wings unspotted, or at most with a few costal spots . . . . . . . . . . . 18

Wings covered with gray and whitish markings . . . . . . . . . . . . 16

16. Markings of wings consist of many small whitish spots on a gray background. 17 Markings consist of a few gray, interrupted crossbands on a whitish hyaline background. Head black, antennæ and mouth parts brown; body black, humeri yellow, scutellum reddish brown, mesonotum opaque, densely gray pruinose, legs dark yellow, middle tibiæ outwardly fringed with rather long yellow bristly hairs, knobs of halteres yellow; wings nearly covered with brown hairs, whitish hyaline, a large gray costal spot near middle of costal cell extending to the fifth vein, an interrupted crossband at tip of first vein, extending to branching of the fifth, an irregular crossband beginning beyond apex of third vein and extending to apex of upper branch of the fifth, forming a border to apical portion of both branches of fourth vein; third vein separated from the first except at its middle where it coalesces for a considerable distance, costal vein greatly dilated from beginning of this union nearly to apex of third vein; length, $2 \mathrm{~mm}$................. cockerellii, new species.

Three female specimens, collected by Prof. T. D. A. Cockerell, for whom the species is named. Custer County, Colorado.

\section{Type.-Cat. No. 5468, U.S.N.M.}

17. Upper branch of fourth vein marked with a distinct whitish spot a short distance from its base. Black, legs brown, a whitish ring before apex of each femur and both ends of each tibia, tarsi yellow, knobs of halteres yellow; mesonotum opaque, brown, 2 vittæ in the middle enlarging into a large spot on the posterior half, also a curved row of 3 spots in front of each wing, and the narrow lateral margins light gray pruinose; wings nearly wholly covered with brown hairs, gray, three darker costal spots, one near middle of costal cell, the second on the submarginal cells, the third beyond apex of third vein; a white spot on small cross vein, a costal spot near middle of first posterior cell and a transverse one at three-fourths the length of this cell, one near threefourths length of second posterior cell, one below it in third posterior cell, another near middle of lower branch of fourth vein, one in center of fourth posterior cell, three in anal cell, and a very large one at base of wing; third vein narrowly separated from the first nearly to its middle where it unites for quite a distance, costal vein not dilated; length, $1 \mathrm{~mm}$.. guttipennis, new species.

Six females, collected August 5 by Prof. James S. Hine, who reports that they bite severely. Medina, Ohio.

\section{Type.-Cat. No. 5469, U.S.N.M.}

Upper branch of fourth vein destitute of a white mark. Same as the preceding species with the above and following differences: No dark spot near middle of 
costal cell, a large whitish spot in base of first posterior cell, one in each end of the second posterior cell, none on lower branch of fourth vein, the one in center of fourth posterior cell extended to margin of wing, only two in anal cell, situated near its apex along the fifth vein; length, nearly $1 \mathrm{~mm}$.

stellifer, new species.

A female specimen, collected June 6 by Mr. H. S. Barber. Washington, District of Columbia.

$$
\text { Type.-Cat. No. 5470, U.S.N.M. }
$$

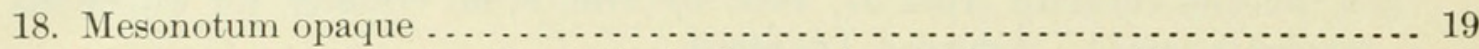

Mesonotum polished. Head black, face and mouth parts yellow, antennæ dark brown, thorax yellow, mesonotum, except the broad anterior corners and a large spot in front of scutellum, black, pleura spotted with brown; scutellum yellow, middle at base brown; abdomen dark brown, becoming yellowish at apex; legs yellow, destitute of long hairs, knobs of halteres light yellow; wings hyaline, bare except along the apex, third vein beyond its base narrowly separated from the first, but coalescing before its apex, first not extending to middle of third; length, $1 \mathrm{~mm} . . . \ldots . . . . . . . . . . .$. levis, new species. A female specimen, collected May 13 by Mr. H. S. Barber. Marlboro, Maryland.

\section{Type.-Cat. No. 5471, U.S.N.M.}

19. Wings almost wholly covered with brown hairs..................... 20

Wings bare except the apical fourth, which bears a few scattered brown hairs. Head brown, antennæ largely yellow, thorax and scutellum dark brown, mesonotum light gray pruinose, abdomen black, legs yellow, knobs of halteres whitish, wings pale grayish, indistinctly mottled with whitish, a small brown stigmal spot between two whitish ones, third vein beyond its base separated from the first, but at its middle coalescing for a short distance, first reaching two-thirds length of third and greatly dilated at its apex, as is also the costal vein at the same point; length, nearly $1 \mathrm{~mm}$......... sanguisuga, new species.

A female specimen, collected May 13 by Mr. H. S. Barber, who reports that it was captured while in the act of biting him. Marlboro, Maryland.

\section{Type.-Cat. No. 5472, U.S.N.M.}

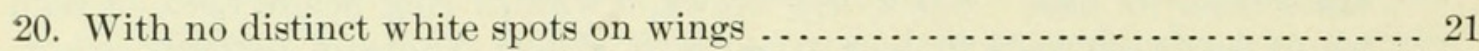

With a distinct white spot on the small cross vein and another at apex of third vein. Head, including its members, dark brown, thorax blackish brown, mesonotum gray pruinose, scutellum dark yellow, abdomen black, almost velvety, legs dark yellow, destitute of long hairs, knobs of halteres yellow, wings grayish hyaline, a darker stigmal spot, third vein beyond its base free from the first, at its middle coalescing for a considerable distance, first reaching three-fourths length of third, costal vein distinctly dilated at apex of first; length, $1 \mathrm{~mm}$............................... biguttatus, new species.

A female specimen, collected June 6 by Mr. H. S. Barber. Washington, District of Columbia.

\section{Type.-Cat. No. 5473, U.S.N.M.}

21. Thorax yellow. Yellow, sides of abdomen tinged with brown, second joint of hind tarsi two-thirds as long as the first, wings hyaline, third vein beyond its base narrowly separated from the first, at its middle coalescing for a short distance, first reaching three-fourths length of third, costal vein at apex of first greatly dilated; length, $1 \mathrm{~mm}$.................... melleus, new species. A female specimen, collected by Mrs. A. T. Slosson. Lake Worth, Florida.

$$
\text { Type.-Cat. No. 5474, U.S.N.M. }
$$


Thorax black, the anterior corners yellow. Head black, antennæ and mouth parts brown, mesonotum gray pruinose, scutellum yellow, the middle brown, abdomen black, somewhat velvety, narrow hind margins of the segments yellow, legs dark yellowish, knobs of halteres brown, wings hyaline, third vein extending close to first and to costal vein, at its middle connected with first by a cross vein; length, 1 to $1.5 \mathrm{~mm}$............. cinctus, new species.

Three female specimens, collected by Mrs. A. T. Slosson, who writes that she braved their biting in order to collect them. Lake Worth and Biscayne Bay, Florida.

\section{Type.-Cat. No. 5475, U.S.N.M.}

22. Hind tarsi each bearing a single very long claw which bears a small claw near base of under side, empodia wanting . . . . . . . . . . . . . . . . .

Hind and other tarsi each bearing the usual pair of claws of an equal length. 23

23. Empodia wanting, last tarsal joint at least twice as long as the preceding .... 24 Empodia large, obovate, last tarsal joint only slightly longer than the preceding. Head black, face, mouth parts, and antennæ brown, hairs of male antennæ black, their apices yellowish, or almost wholly yellow, eyes contiguous; body black, the scutellum and genitalia of male brownish yellow, mesonotum slightly polished, knobs of halteres white, legs yellow, femora and tarsi not spined on under side, tarsal claws simple; wings hyaline, first vein nearly reaching middle of third, the latter beyond its base narrowly separated from the first, before apex of the latter connected with it by a cross vein, ending near three-fourths length of wing; fourth forking slightly beyond the small cross vein; length, $2 \mathrm{~mm}$...................... fusculus, new species.

Three males and four females. Washington, District of Columbia (May 12, F. C. Pratt); Riverton, New Jersey (April 30, C. W. Johnson); Mount Washington, New Hampshire (Mrs. A. T. Slosson); and Waldoboro, Maine (J. H. Lovell),

\section{Type.-Cat. No. 5476, U.S.N.M.}

24. Mesonotum opaque, densely light gray pruinose. Head black, eyes contiguous, mouth parts and basal joint of antennæ brown (remainder of antennæ wanting); thorax black, pleura thinly gray pruinose, scutellum brownish yellow, abdomen brown, rather densely whitish pruinose, legs blackish brown, tarsi yellow, apex of each joint and whole of last one black, claws very long, nearly straight, and with a pair of small claws near their bases, last tarsal joint bearing many long spinous bristles on the under side, femora slightly thickened toward their apices, each bearing 3 or 4 short spinous bristles toward apex of under side; wings hyaline, first vein almost reaching middle of third, the latter widely separated from the first, before apex of latter connected with it by a cross vein, reaching about five-sixths length of wing, fourth forking slightly before the small cross vein; length, $3.5 \mathrm{~mm}$.......... schwarzii, new species.

A female specimen, collected May 5 by Mr. E. A. Schwarz, for whom this fine species is named. Sharpsburg, Texas.

\section{Type.-Cat. No. 5477, U.S.N.M.}

Mesonotum somewhat polished but roughened, slightly rugose and granulose, not pruinose. Head brown, eyes widely separated, antennæ brown, the basal joint and mouth parts yellow; body black, halteres dark brown, legs yellow, apices of hind femora and of their tibiæ black, front femora noticeably thickened, each bearing about 5 short spines on the under side, middle and hind femora considerably thickened near the apex, each bearing two or three spines on the under side, last tarsal joint fringed along each side below with stout and rather long bristles, claws long, simple; wings hyaline, first vein 
reaching about to middle of the third, the latter widely separated from the first, only connected by a cross vein, apex of third near seven-eighths length of wing, fourth forking slightly before the small cross vein; length, $2 \mathrm{~mm}$. subasper, new species.

Two female specimens. Marlboro, Maryland (May 13, H. S. Barber), and Mesilla, New Mexico (T. D. A. Cockerell).

\section{Type.-Cat. No. 5478, U.S.N.M.}

25. Front and middle tarsi each furnished with the usual pair of claws, of an equal

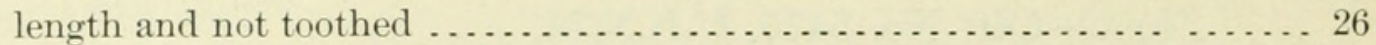

Front and middle tarsi each furnished with a single very long claw, which bears a small one near base of under side, last tarsal joint about twice as long as the preceding, femora destitute of spinous bristles, first vein reaching one-fifth length of the third, the latter separated but connected by a crossvein, apex of

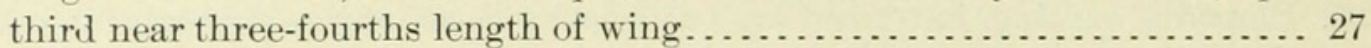

26. Wings marked with three brownish spots or bands, the first near center of first basal cell, the second beginning at basal part of third vein and extending to apex of lower branch of fifth, the last beginning on costa beyond apex of third vein and extending into the second posterior cell; also a small brownish spot near center of anal cell. Head and first antennal joint brownish black, remainder of antennæ yellow, the apex brown, the hairs yellow, tipped with brown; eyes contiguous; thorax black, mesonotum opaque, densely gray pruinose and marked with large, mostly confluent spots and isolated dots of brown; scutellum yellow, the front corners brown; abdomen polished, black, basal half of the dorsum yellowish, knobs of halteres whitish; legs brownish black, tarsi yellow, femora destitute of spinous bristles on the under side, hind tarsi on under side bearing a spine at base of first joint and a pair at apices of first two joints, last two joints of nearly an equal length, destitute of spinous bristles; first vein reaching about to middle of the third, the latter separated but connected by a crossvein; apex of third near three-fourths length of wing, fourth forking slightly beyond the small crossvein; length, nearly $2 \mathrm{~mm} . . . \ldots \ldots . . . . . . . .$. nebulosus, new species. A male specimen, collected June 19 by Mr. C. W. Johnson. Riverton, New Jersey.

Type.-Cat. No. 5479, U.S.N.M.

Wings unmarked, hyaline. Brownish black, knobs of halteres whitish, tarsi yellow; joints three to five of antennæ broader than long, eyes very widely separated, mesonotum and abdomen highly polished, femora and tarsi destitute of spinous bristles on the under side, last tarsal joint almost twice as long as the preceding; first vein almost reaching middle of the third, the latter lying close to the first, with which it is connected by a crossvein; apex of third almost at two-thirds length of wing, lower branch of fourth obliterated at its base; length,

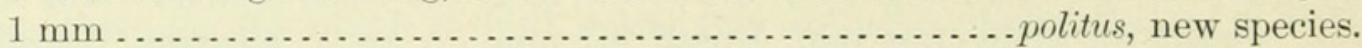
A female specimen, collected April 2. Cambridge, Massachusetts.

Type.-Cat. No. 5480, U.S.N.M.

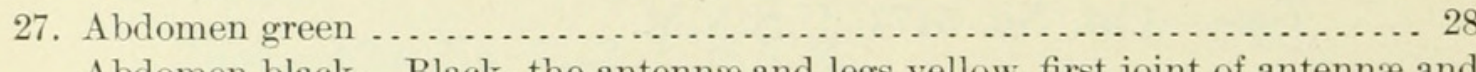

Abdomen black. Black, the antennæ and legs yellow, first joint of antennæ and the mouth parts yellowish brown, middle and hind coxæ and their femora brown; eyes contiguous, antennæ nearly as long as the head and body, each joint, except the first, over twice as long as broad, mesonotum and abdomen highly polished, last joint of each tarsus bearing a transverse pair of blunt spines near base of under side; wings hyaline, fourth vein forking far beyond the small crossvein; length, $1.5 \mathrm{~mm}$............... antennalis, new species. Two females, collected by the writer in June. District of Columbia.

Type.-Cat. No. 5481, U.S.N.M. 
28. Thorax and scutellum black. Head and its members yellow, eyes contiguou, antennæ, last tarsal joint, wings, and fourth vein as in the preceding species, mesonotum highly polished, halteres and legs light yellow; length, $1.5 \mathrm{~mm}$.

diversus, new species.

A female specimen, collected July 3 by Mr. C. W. Johnson. Riverton, New Jersey.

Type.-Cat. No. 5482, U.S.N.M.

Thorax and scutellum green. Head, eyes, antennæ, last tarsal joint, wings, and fourth vein as in the preceding species; abdomen marked with a transverse pair of elongate, velvet black spots on the third and fifth segments; halteres and legs light yellow, apices of hind femora and of their tibiæ black; length,

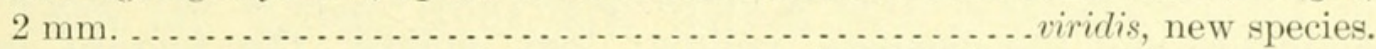

A female specimen, collected June 16 by Mr. C. W. Johnson. Riverton, New Jersey.

Type.-Cat. No. 5483, U.S.N.M.

CHIRONOMUS BRACHIALIS, new species.

Male.-Head black, the face brownish yellow, mouth parts brown, first joint of antennæ black, the others yellow, hairs of antennæ pale yellow changing into white at their apices; thorax and scutellum black, polished; abdomen yellow, middle of dorsum of second segment, prolonged to the lateral margin at the hind end, on the front end extending entirely around the segment, narrow bases of the three succeeding segments and whole of the following ones, including the genitalia, brown; legs yellow, apex of front femora, front tibiæ and their tarsi except basal two-thirds of first joint, knees of other legs, apices of their tibiæ, sutures of first three tarsal joints and whole of the two following brown, front tarsi fringed with rather long hairs on outer side of second and third joints; wings bare, the basal portion hyaline and with yellow veins, the remainder grayish hyaline and with brownish veins, an indistinct darker brown spot on the small crossvein; halteres yellow. Length, $5 \mathrm{~mm}$.

Female.-As in the male except that the first antennal joint is yellow, broad humeral region tinged with yellow, second and three following abdominal segments largely brownish (front tarsi wanting), wings with a broad brown crossband which in its outer portion includes the small crossvein.

Two males and one female, collected June 27 by Mr. C. W. Johnson. Habitat.-Westville, New Jersey.

Type.-Cat. No. 5484, U.S.N.M.

CHIRONOMUS T $\rightleftarrows N I A P E N N I S$, new species.

Yellow, tinged in places with green, especially on the abdomen, mouth parts, apical half of the femora, bases of front and middle tibiæ and nearly the whole of the hind ones brown, metanotum marked with a transverse pair of triangular brown spots; wings whitish, the costal cell from humeral crossvein to apex of auxiliary vein, a crossband 
extending from the latter point to hind margin of wing where it is greatly dilated, finally the apical fourth of wing black. Length, $4 \mathrm{~mm}$. Two female specimens.

Habitat.-Andover, Massachusetts (June 14); and Delaware Water Gap, New Jersey (July 11, C. W. Johnson).

Type.-Cat. No. 5485, U.S.N.M.

CHIRONOMUS NITIDULUS, new species.

Head black, mouth parts yellow, antennæ except the basal joint yellow, the hairs whitish; body black, polished, the first two abdominal segments and the claspers yellow; legs yellow, the femora except their bases, front tibiæ wholly, and apices of hind ones brown, front tarsi bare; wings bare, whitish hyaline, the veins brown, halteres yellow; length, $2.5 \mathrm{~mm}$. A male specimen, collected May 14 by Mr. C. W. Johnson.

Habitat.-Riverton, New Jersey.

Type.-Cat. No. 5486, U.S.N.M.

ORTHOCLADIUS PAR, new species.

Yellow, the antennæ except the basal joint, apices of front femora, of their tibiæ and of their first two tarsal joints, the whole of the remaining joints, also the last two on the other tarsi, brown, a pair of rather large black spots on abdominal segments 2 to 11 ; mesonotum marked with three darker yellow vittæ, hairs of antennæ bright yellow, becoming brownish at their apices; front tarsi destitute of long hairs, the fourth joint more than one-third as long as the first; wings bare, whitish hyaline, the portion in front of the first and third veins dark gray, the veins brownish; length, $6 \mathrm{~mm}$. A male specimen, collected July 3 by Mr. C. W. Johnson.

Habitat.-Riverton, New Jersey.

Type.-Cat. No. 5487, U.S.N.M.

EURYCNEMUS SCITULUS, new species.

Yellow, the palpi, apices of antennæ, four vittæ on the mesonotum, a small spot below and slightly in front of each wing, the metanotum except the upper margin and sides, a broad fascia at base of abdominal segments 2 to 7 , the knees, apices of tibiæ and of the tarsal joints, dark brown; mesonotum subopaque, front tarsi bare; wings almost wholly covered with brown hairs, grayish hyaline, the portion in front of the first and third veins pale brown, veins brown; length, $4 \mathrm{~mm}$. A female specimen, collected April 30 by Mr. C. W. Johnson.

Habitat.-Riverton, New Jersey.

Type.-Cat. No. 5488, U.S.N.M. 
TANYPUS JOHNSONI, new species.

Male.--Yellow, the scutellum, halteres, and tarsi white, apical joint of the latter, a band before apex of each femur and near base of each tibia brown, abdomen whitish, each segment with an irregular brown mark, composed principally of two median vittæ and a posterior arcuate fascia, most distinct on the median segments, on the apical ones expanded so as to cover nearly the entire dorsum; hairs of antennæ mixed pale yellow and brown, their apices chiefly whitish, mesonotum opaque, whitish pruinose, in certain lights three dark yellow vittæ are visible; front tarsi clothed with very short hairs, the first joint two-thirds as long as the tibia; wings whitish hyaline, almost wholly covered with yellow hairs, humeral cross vein bordered with brown, a broad pale brownish fascia crosses the wing just before the small cross vein, and a second slightly broader one at apex of first vein, fifth vein forking a short distance before the small cross vein; length, $3.5 \mathrm{~mm}$.

Female.-Differs from the male as follows: Abdomen with dark yellow mottlings, destitute of brown markings, hairs of antennæ whitish, vittæ of mesonotum more distinct; length, $3 \mathrm{~mm}$.

A specimen of each sex, collected June 17 and 18 by Mr. C. W. Johnson.

Habitat.-Riverton, New Jersey.

Type.-Cat. No. 5489, U.S.N.M.

TANYPUS BIFASCIATUS, new species.

Male.-Differs from johnsoni as follows: Front corners of scutellum brown, apical joint of tarsi white, no brown band on femora nor on tibiæ, brown of abdomen confined to a fascia at base of segments 2 to 6 and middle of dorsum of the seventh (front tarsi wanting), hairs of wings chiefly brown, humeral cross vein not bordered with brown, the first fascia lies beyond the small cross vein; length, $4 \mathrm{~mm}$.

Female.-Hairs of antennæ whitish, abdomen yellow, destitute of brown markings, otherwise as in the male; length, $2.5 \mathrm{~mm}$.

A specimen of each sex.

Mabitat.-Riverton, New Jersey (April 30, C. W. Johnson); and Boston, Massachusetts.

Type.-Cat. No. 5490, U.S.N.M.

FAMILY EMPIDIDA.

EMPIS TRIDENTATA, new species.

Head black, gray pruinose, front of male at narrowest point less than width of lowest ocellus; antennæ black, the first two joints yellow,

Proc. N. M. vol. xxiii- 39 
the third slightly over four times as long as wide, gradually tapering to the apex, nearly four times as long as the style, palpi and proboscis yellow, the latter almost twice as long as height of head; thorax yellow, a large black, gray pruinose spot in middle of hind part of mesonotum, sending three long prongs toward the head, the median one subopaque, the lateral ones polished, three small black spots beneath insertion of each wing, and a fourth bordering the mesothoracic spiracle and prolonged backward almost to the wing, hairs and bristles of thorax black, scutellum yellow, the base in the middle black, bearing four bristles; abdomen polished, yellow, bases of segments 2 to 4 or 5 usually black, most extended in the female, central filament of male hypopygium very sinuous; legs yellow, apices of tarsi brown, middle and hind femora beset with spinous bristles on the under side; wings hyaline, stigma brown, a brown cloud on base of upper branch of third vein, another on vein at base of second posterior cell, and one above forking of second and third veins; length, 5 to $6.5 \mathrm{~mm}$. Two males and one female, collected June 12 by Mr. C. W. Johnson.

Habitat.-Delaware County, Pennsylvania.

Type.-Cat. No. 5491, U.S.N.M.

RHAMPHOMYIA CLAUDA, new species.

Male.-Head black, gray pruinose, eyes contiguous, antennæ black, the third joint five times as long as broad, nearly five times as long as the style, mouth parts brown, proboscis scarcely longer than height of head; thorax and scutellum black, opaque, gray pruinose, hairs and bristles black, scutellum bearing four bristles, abdomen dark brown, subopaque, hairs brown, hypopygium small, upper pieces usually yellow, gibbous, a clavate projection tipped with bristles in front of each clasper about half as long as the latter, central filament usually free except at apex, widely dilated near the middle; legs yellow, apices of tarsi, nearly the whole of hind ones, and sometimes of middle ones, hind femora except their bases, also a spot on under side of the hind trochanters, brown, all coxæ and greater part of femora sometimes brown; hind femora each greatly enlarged toward the apex, dilated before apex of anterior under side where it bears many black hairs; hind tibiæ greatly bent inward at the middle, suddenly dilated laterally on the basal third, bearing a small rounded lobe on the anterior inner side at one-fifth length of tibia from the base, beyond which is a large concavity reaching almost to middle of tibia; wings hyaline, veins brownish, stigma pale gray, sixth vein prolonged to the wing margin; halteres yellow; length 3.5 to $4 \mathrm{~mm}$. Two specimens.

Mabitat.-Clementon, New Jersey (May 10, C. W. Johnson); and Mount Washington, New Hampshire (Mrs. A. T. Slosson).

Type.-Cat. No. 5492, U.S.N.M. 


\section{RHAMPHOMYIA DIVERSA, new species.}

Female.-Head black, gray pruinose, antennæ black, the third joint oval, scarcely one-half longer than broad, about three times as long as the style, mouth parts dark brown, proboscis scarcely longer than height of head; thorax black, opaque, gray pruinose, marked on mesonotum with three black vittæ, hairs and bristles black; scutellum black, gray pruinose, bearing four bristles; abdomen dark brown, subopaque, thinly gray pruinose, the hairs black; legs brown, the knees yellow, middle and hind femora ciliate on their upper and under sides, the hind tibiæ on their outer and inner sides with short flattened bristles; wings pale brown, darker in the costal and marginal cells, venation normal, sixth vein prolonged to the wing margin; halteres yellow; length, $4.5 \mathrm{~mm}$. A single specimen, collected May 9 by Mr. C. W. Johnson.

Mabitat.-Clementon, New Jersey.

Type.-Cat. No. 5493, U.S.N.M.

[RHAMPHOMYIA MACRURA Coquillett, Igoo, not Loew, I871.

Change name to $R$. clavator Coquillett, new name.]

\section{Family SYRPHID A.}

\section{CRIORHINA KINCAIDI, new species.}

Head black, gray pruinose, a large brown pruinose spot above the antennæ, center of front and the cheeks polished, eyes at narrowest part of front as widely separated as the posterior ocelli, first two joints of antennæ black, the second slightly shorter than the first, but slightly longer than the third which is brownish yellow and about twice as wide as long, arista black, face deeply concave on its upper part, then strongly convex and with a prominent, rounded central tubercle, narrow sides of face along the eyes densely covered with long yellowish hairs, proboscis rather slender, rigid, the portion beyond the basal articulation slightly over half as long as height of head, narrow at the apex; thorax and scutellum black, densely yellow pilose, the posterior half of the mesonotum except the hind angles black pilose; abdomen black, yellow pilose, the third and fifth segments and genitalia largely black pilose; femora black, densely covered with long, chiefly yellow hairs, the hind femora strongly arcuate, not as robust as the others, tibiæ and tarsi brown, the hind tibiæ strongly arcuate; wings tinged with pale brown along the veins, the base and stigma yellowish; length, $23 \mathrm{~mm}$. A male specimen, collected by Prof. Trevor Kincaid, for whom this fine species is named.

Habitat.-Seattle, Washington.

Type.-Cat. No. 5494, U.S.N.M. 


\section{Family SCATOPHAGIDA.}

\section{SCATOPHAGA NUBIFERA, new species.}

Head black, face yellow, the cheeks, face, and sides of front gray pruinose, occiput brownish gray pruinose, a broad vertical dark brown stripe on the upper half, a velvet black circle around the ocelli, frontal vitta deep velvety brownish red; antennæ black, the first two joints and base of the third reddish yellow, arista bare, proboscis blackish, palpi yellow; body black, brownish pruinose, the hairs mostly yellowish, rather short and sparse, the dorsocentral bristles in front of the suture noticeably longer and stouter than the adjacent hairs, pteropleura hairy; hypopygium yellowish; coxæ and femora black, apices of the latter, the tibiæ and tarsi reddish yellow, femora destitute of bristles, the hairs chiefly yellow, rather short and sparse on the middle and hind ones, front tibiæ destitute of bristles, middle tibiæ each bearing one on the outer and two on the inner side below the middle, hind tibiæ each with two bristles on the inner side below the middle and two rows of about four each on the outer side, besides those at the tip; wings grayish, small and hind cross veins clouded with brown; length, 7 mm. A male specimen, collected July 13, 1882, by Mr. John Murdock.

Habitat.-Point Barrow, Alaska.

Type.-Cat. No. 5495, U.S.N.M.

SCATOPHAGA CRINITA, new species.

Differs from the above description of nubifera only as follows: Occiput bluish gray pruinose, no velvet black circle around the ocelli, frontal vitta reddish brown, antennæ black, extreme apex of second joint reddish brown, body bluish gray pruinose, hairs of mesonotum rather long, black, bristle like, those of the abdomen unusually long, crinkled, reddish yellow, dorsocentral bristles not stouter than many of the adjacent hairs, pteropleura bare, hypopygium and entire legs black, hairs of legs unusually long and rather abundant, middle tibiæ each bearing one or two stout bristles and several bristly hairs on the outer side, hind tibiæ destitute of bristles, wings grayish hyaline, cross veins not bordered with brown; length, $10 \mathrm{~mm}$. A male specimen, collected in July or August, 1897, by Mr. Barrett-Hamilton.

Habitat.-Bering Island.

Type.-Cat. No. 5496, U.S.N.M.

\section{HEXAMITOCERA FLAVIDA, new species.}

Yellow, an ocellar dot and hind margins of the first three abdominal segments, black, bristles and most of the hairs also black; front much narrowed anteriorly, at the lower end less than half as wide as either eye, three pairs of fronto-orbitals, antennæ four-fifths as long as the face, 
the third joint only slightly longer than the second, arista bare; five pairs of dorsocentral bristles, two humeral, propleural and sternopleural bristles, three on hind margin of the mesopleura, pteropleura bare, scutellum bearing a very long median pair of macrochæta; all femora bristly, front tibiæ each bearing a bristle on the front and hind sides, middle tibiæ with one on the front and two on the hind side, hind ones each with two pairs on the outer side; wings hyaline, unmarked; length, $5 \mathrm{~mm}$. A male specimen, collected by Mrs. A. T. Slosson.

Habitat.-Franconia, New Hampshire.

Type:-Cat. No. 5497, U.S.N.M.

PYCNOGLOSSA, new genus.

Form rather short and robust, head in profile somewhat trapezoidal, under side of the head strongly drawn upward at the anterior end, bearing about four strong bristles, vibrissæ well developed, face slightly concave, antennæ almost as long as the face, deflexed, the third joint somewhat oval, rounded at the apex, slightly longer than wide, about twice as long as the second, arista sub-basal, plumose nearly to the tip, the penultimate joint scarcely longer than broad; frontal bristles descending nearly to base of antennæ; eyes oval, cheeks less than one-fifth as wide as the eye-height; proboscis excessively large and thick, about as long as height of head, palpi slightly clavate, bearing: a few short bristly hairs at the apex; thorax bearing five dorsocentrals, one præsutural, one intrahumeral, two humeral, two posthumeral, four supra-alar, two intra-alar, two propleural, a row along the hind margin of the mesopleura, and three sternopleural bristles; abdomen elongate oval; all femora and tibiæ bristly, no erect bristle on inner side of the front tibiæ; lower calypteres scarcely apparent, venation of wings practically as in Scatophaga, costa beset with rather short bristly spines, and with a longer pair at apex of the auxiliary vein.

Type, the following species:

\section{PYCNOGLOSSA FLAVIPENNIS, new species.}

Black, the halteres yellow, face, sides of front and greater part of cheeks gray pruinose, body somewhat polished; scutellum bearing four long bristles and a few short bristly hairs, pteropleura bare; wings unusually short and broad, strongly tinged with yellow, the veins also yellow; length, $5 \mathrm{~mm}$. A female specimen, collected by Prof. O. B. Johnson.

Mabitat.-Washington.

Type.-Cat. No. 5498, U.S.N.M.

\section{PLETHOCH ЕTA, new genus.}

Differs from the above description of Pycnoglossa only as follows: Under side of head fringed with about ten bristles, antennæ three- 
fifths as long as the face, the third joint only slightly longer than the second, arista bare, proboscis small, about half as long as height of head, palpi at apex each bearing a black bristle as long as the palpi, costa of wings destitute of bristly spines.

Type, the following species:

PLETHOCHÆTA VARICOLOR, new species.

Head yellow, an ocellar spot and a transverse spot above center of occiput, black; face, cheeks, and sides of front whitish pruinose, frontal vitta dark yellow, changing above into yellowish brown; antennæ brownish black, the first two joints yellow; proboscis black, palpi yellow; thorax black, opaque, gray pruinose, the humeri and hind angles reddish yellow, pteropleura bare, scutellum reddish yellow, the upper surface brown, bearing a few short bristly hairs, a pair of very long submedian bristles, a pair of short basal ones, and a short apical pair; abdomen reddish yellow, the hind margins of first three segments and the genitalia brownish; legs yellow, tarsi brownish, front tibiæ each bearing one bristle on the front and one on the hind side, middle tibiæ with one on the inner, one on the front, and two on the hind side, hind tibiæ with one on the inner, three on the front, and four on the hind side; wings grayish hyaline, unmarked, halteres yellow; length, $8 \mathrm{~mm}$. A female specimen, collected August 19, 1892, by Mr. C. W. Johnson.

Habitat.-Delaware County, Pennsylvania.

Type.-Cat. No. 5499, U.S.N.M.

\section{Family HELOMYZID}

\section{ANOROSTOMA OPACA, new species.}

Head yellow, opaque, white pruinose, the front and upper part of the occiput tinged with bluish gray, a velvet black spot between the antennæ and each eye, antennæ brownish, the arista marked before its middle with a white ring, palpi yellow, proboscis brown; body brown, opaque, bluish gray pruinose, mesonotum with four, the pleura with one brownish pruinose vittæ; sternopleura bearing numerous short bristly hairs and with two stout bristles; legs yellow, opaque grayish pruinose except a polished spot at base of the posterior side of the first two pairs and a streak on the posterior side of the hind ones; wings whitish, marked with large pale gray spots and with a black cloud covering the small and hind crossveins, a small black spot beneath apex of auxiliary vein, one slightly before middle of antepenultimate section of the fourth vein, and several smaller spots on some of the other veins; the gray color fills the whole marginal cell beyond apex of auxiliary vein, nearly the entire second half of 
the submarginal, etc.; length, $7 \mathrm{~mm}$. A female specimen captured by the writer.

Mabitat.-Los Angeles County, California.

Type.-Cat. No. 5500, U.S.N.M.

Family SCIOMYZID E.

TETANOCERA SETOSA, new species.

Head yellow, the face, cheeks, occiput, and narrow lateral margins of the front, white pruinose, an elongated brown spot below lower end of each eye, a brown ocellar dot, front opaque, a median line and streak at each lower corner, brown, antennæ yellow, the third joint orange yellow, slightly shorter than the very broad second joint, the latter bearing two strong spines near apex of upper side, the third joint considerably concave on the outer upper portion, arista black, long plumose, palpi yellow, proboscis brownish; body brown, thinly whitish pruinose, mesonotum marked with four brown vittæ, the median pair very narrow, a broad brown vitta on upper part of pleura and two on the scutellum; mesopleura covered with short hairs and with two bristles along the hind edge, pteropleura bearing one or two bristles, otherwise bare, sternopleura covered with short hairs and bearing a single bristle; halteres and legs yellow, apices of tibiæ brown; wings pale brownish, darker brown in the marginal cell, covered with pale yellowish and whitish dots and spots, the largest located in the marginal cell; length, 6 to $7 \mathrm{~mm}$. Nine specimens, of both sexes.

Habitat.-New Bedford (Dr. Garry de N. Hough) and Barnstable (August 5, E. Burgess), Massachusetts and Georgia (H. K. Morrison). Type.-Cat. No. 5501, U.S.N.M.

SCIOMYZA GUTTATA, new species.

Head yellow, upper part of occiput and three vittæ on upper half of front black, gray pruinose, a brown dot at base of each bristle, front opaque, two pairs of orbital bristles, a velvet black spot on each side of base of antennæ, the latter yellow, along the upper edge brown, arista brown, short plumose, mouth parts yellowish; body black, thickly detted with brown, a brown vitta on upper part of pleura and one on the sternopleura, a brown spot in center of scutellum; posterior upper corner of mesopleura and upper portion of sternopleura bearing many short hairs, pteropleura bearing one or two bristles and a few hairs; legs brown, the front coxæ, a ring beyond middle of each middle and hind femur, the middle tibiæ except their apices, middle of each hind tibiæ and the middle and hind tarsi except their apices, yellow; knobs of halteres brown, the stems yellow; wings 
pale brownish, darker brown along outer half of costa and at apex, thickly covered with whitish hyaline dots except the apex, marginal cell beyond apex of first vein containing two pairs of whitish spots, and a small dot in its extreme apex; length $3 \mathrm{~mm}$. A female specimen.

Habitat.-Texas.
Type.-Cat. No. 5502 , U.S.N.M.

SCIOMYZA ALBOVARIA, new species.

Head yellow, upper part of occiput and three vittæ on the front black, gray pruinose, the median vitta reaching slightly below center of front and bordered each side with orange brown, the lateral ones each forming a tooth below the lowest of the two frontal bristles, below which it is very narrowly extended to lower end of the front, a biack or brown spot on each side of base of antennæ, one on lower part of face, two on each cheek and one near middle of each occipital orbit; antennæ orange yellow, the arista brown, rather long plumose, its base and the mouth parts yellow, apices of palpi brown; thorax brown, grayish pruinose, mesonotum marked with four brown vittæ, a broad brown vitta on upper part of pleura and usually one on the sternopleura; mesopleura bare, a few short hairs above the front coxæ, pteropleura bearing one or two bristles and a few hairs, sternopleura covered with short hairs; scutellum yellowish, a central brown spot; abdomen polished, brown, apices of the segments and male genitalia yellowish, opaque, gray pruinose; legs of male yellow, bases of middle and hind coxæ and both ends of all femora and tibiæ brown, tarsi toward their apices brownish, the last joint yellowish-white; in the female the front femora and joints 2 to 4 of front tarsi blackish, 5 brown, 1 whitish; wings whitish hvaline, costal cell purer white, costal margin beyond apex of first vein continued around apex of wing, and a border to most of the veins except the first three, brown, veins brown, the humeral crossvein, auxiliary and first vein, except middle of the latter, usually the first section of the third, and the second vein from near its base to apex of the first, whitish; halteres yellow; length, 3 to $5 \mathrm{~mm}$. Two males and three females.

Habitat.-New York (Nathan Banks); White Mountains, New Hampshire, and North Carolina (H. K. Morrison).

Type.-Cat. No. 5503, U.S.N.M.

NEUROCTENA FUMIDA, new species.

Head and its members yellow, the front, except its upper angles and an ocellar spot, dark velvety orange, shading below into light yellow; antennal arista pubescent, apically brown; thorax, scutellum, and legs reddish yellow, tarsi black; abdomen black, base of first segment and apex of abdomen beyond hind margin of fifth reddish yellow; halteres 
yellow; all hairs and bristles except those of the calypteres black; wings gray, the extreme bases yellowish, apex of first vein considerably beyond the small crossvein; length, $5.5 \mathrm{~mm}$. A female specimen, collected August 17 by Prof. T. D. A. Cockerell.

Habitat.-Beulah, New Mexico.

Type.-Cat. No. 5504, U.S.N.M.

\section{DRYOMYZA ARISTALIS, new species.}

Head light yellow, front polished, a brown fascia on its lower part, face, except on the sides, highly polished, blackish brown, antennæ yellow, the third joint ellipsoidal, arista black, very thick at base, densely covered with long black hairs, clypeus not projecting, proboscis dark yellow, palpi yellowish, the apices brown; body reddish yellow, polished, one bristle and a few short hairs above each front coxæ, several short hairs on upper hind corner of the mesopleura, which is otherwise bare, pteropleura bearing one or two bristles and a few short hairs, sternopleura covered with short hairs but destitute of bristles; legs light yellow, a brown spot on apical portion of anterior side of each front femur, front tibiæ and their tarsi black, apices of other tarsi brown; wings hyaline, base of submarginal cell slightly before base of discal, apex of first vein opposite the small crossvein; all hairs and bristles, except those on the calypteres, black; length, $7 \mathrm{~mm}$. A female specimen, collected by Mr. W. Hague Harrington.

Habitat. -Ottawa, Canada.

Type.-Cat. No. 5505, U.S.N.M.

\section{Family PSILID E.}

\section{PSILA FRONTALIS, new species.}

Yellow, polished, the frontal triangle, reaching nearly to lower end of the front, black, polished, antennal arista and bristles of head and body black, the arista pubescent; antennæ slightly over half as long as face, the third joint one-half longer than broad, eyes slightly higher than long; wings yellowish hyaline, the veins yellow; length, 3 to 3.5 mm. Two males and one female, the latter collected by Mrs. Annie T. Slosson.

Habitat.-Franconia, New Hampshire.

Type.-Cat. No. 5506, U.S.N.M.

\section{LOXOCERA FUMIPENNIS, new species.}

Head yellow, three spots on upper part of occiput, the front except the orbits, and the face except a triangular spot in middle of lower part, black; front subopaque, the large triangle highly polished, antennæ linear, almost twice as long as the face, black, the second joint brown, arista nearly bare, yellow, the apical portion whitish; proboscis 
reddish, the palpi yellow; body polished, slightly scabrous, reddish yellow, a median vitta on mesonotum and a dorsal spot on the first abdominal segment, black; legs reddish yellow, apices of tarsi brown; halteres light yellow; wings smoky gray, sometimes nearly hyaline in some of the cells, unusually short and broad; length, 4 to $5.5 \mathrm{~mm}$. Four males and two females.

Habitat.-Baldwin, Kansas (May, J. C. Bridwell); and Texas (Nathan Banks).

Type.-Cat. No. 5507, U.S.N.M.

\section{Family DROSOPHILID无.}

PHORTICA VITTATA, new species.

Head yellow, a black ocellar dot, continued as a pale brown vitta attenuated anteriorly and reaching lower edge of the front, at which point is a black dot, a black dot beneath base of each antennæ, one at base of each vibrissa extending as a pale brown streak on the adjacent cheek, a black mark above insertion of the neck, antennæ and proboscis yellow, palpi velvet black; thorax and scutellum yellow, mesonotum polished, marked with 4 to 7 black vittæ, pleura marked with a broad black median vitta; abdomen yellow, middle of dorsum largely brown or black, most extended on the hind margins of the segments, two lateral vittæ, not visible from above, and apex of venter brown; legs whitish, a brown band near apex of each middle and hind femur; wings dark brown, becoming hyaline along the hind margin; halteres yellow; length, 3 to $4 \mathrm{~mm}$. Three specimens.

Habitat.-Avalon (June 8), and Delaware Water Gap, New Jersey (July 12, C. W. Johnson); and New York (Nathan Banks).

Type.-Cat. No. 5508, U.S.N.M. 


\section{$2 \mathrm{BHL}$ Biodiversity Heritage Library}

Coquillett, D. W. 1901. "New Diptera in the U.S. National Museum." Proceedings of the United States National Museum 23, 593-618. https://doi.org/10.5479/si.00963801.23-1225.593.

View This Item Online: https://www.biodiversitylibrary.org/item/32360

DOI: https://doi.org/10.5479/si.00963801.23-1225.593

Permalink: https://www.biodiversitylibrary.org/partpdf/26646

\section{Holding Institution}

Smithsonian Libraries

\section{Sponsored by}

Smithsonian

\section{Copyright \& Reuse}

Copyright Status: NOT_IN_COPYRIGHT

This document was created from content at the Biodiversity Heritage Library, the world's largest open access digital library for biodiversity literature and archives. Visit BHL at https://www.biodiversitylibrary.org. 